\title{
Quantifying climatic change through the last glacial-interglacial transition based on lake isotope palaeohydrology from central Turkey
}

\author{
Matthew D. Jones ${ }^{1 *}, 2$ C. Neil Roberts ${ }^{2}$ and Melanie J. Leng ${ }^{3,1}$
}

1. School of Geography, University of Nottingham, University Park, Nottingham, NG7 2RD. UK.

2. School of Geography, University of Plymouth, Drake Circus, Plymouth, PL4 8AA. UK.

3. NERC Isotope Geosciences Laboratory, British Geological Survey, Nottingham, NG12 5GG. UK.

* address for correspondence.

E-mail: matthew.jones@nottingham.ac.uk, Tel.: +44 (0)115 8468406, Fax.: +44(0)1159514249 


\begin{abstract}
There remain questions as to the nature of climatic change through the last glacial-interglacial transition in the Eastern Mediterranean region, particularly the relative contribution of evaporation and precipitation to regional water balance. Here changes in oxygen isotope values through this time period from Eski Acıgöl, a crater lake in central Turkey, are investigated using hydrological and isotope mass balance models. These allow changes in evaporation and precipitation to be quantified and their relative importance evaluated. We show that it is the volumetric flux rate of water passing through the lake system and not the precipitation to evaporation ratio per se which controlled the stable isotope record in Eski Acıgöl. Early Holocene precipitation is shown to be much greater than that during both the latter part of the last glaciation and the present day. We test these calculated values against other records in the same region, firstly with other lake records in Anatolia, the Konya basin and Lake Van, and secondly, with isotope-inferred palaeo-precipitation data from Soreq cave in Israel. This reveals a contrast between pre- and post-LGM precipitation values in Turkey (wetter and drier, respectively), and also suggests that during the last glacial-interglacial transition there was a more marked precipitation gradient than at present between northern/interior and southern/coastal parts of the East Mediterranean region.
\end{abstract}

Keywords: Oxygen isotope, last glacial maximum, precipitation, Turkey, lakes 


\section{Introduction}

Late Quaternary lake levels have been shown to vary significantly through time in the circum-Mediterranean region (Robinson et al., 2006; Roberts and Wright, 1993; Harrison and Digerfeldt, 1993). Stein (2001), for example, showed that cold periods in northern latitudes are correlated with high-stands of Lake Lisan, Israel, although lake level falls are associated with shorter term cold (Heinrich) events, possibly due to the reduction in precipitation from a cold Mediterranean Sea (Bartov et al., 2003). There has been debate (e.g. ElMoslimany, 1984; Prentice et al. 1992) about the relative contributions of changes in temperature - and hence evaporation - versus precipitation and other factors to the last glacial age lake expansion. There is comparable debate for the Early Holocene period, for which evidence from deep-sea cores, speleothems and at least some lakes supports a more positive water balance than at the present-day (Ariztegui et al., 2000; Bar-Matthews et al., 1997; Fontugne et al., 1994), but conflicts with palaeo-botanical data showing a delayed rate of postglacial forest re-advance in the eastern Mediterranean (van Zeist and Bottema, 1991; Wasylikowa, 2005). Reconstructing past climate from lake palaeohydrology requires a good understanding of which climatic parameters control lake-level change, primarily the relative contribution of evaporation and precipitation. There is need for a more rigorous quantification of palaeolimnological data from the eastern Mediterranean region in terms of climate, and precipitation in particular.

Here we quantify changes in climate through the last glacial interglacial transition (LGIT) and Holocene using $\delta^{18} \mathrm{O}$ values recorded in a high-resolution lake sedimentary archive from Eski Acıgöl, central Turkey, by means of coupled hydrological and isotope mass balance modelling. The palaeohydrology of this crater lake is relatively simple and we use this lake system to calculate changes in climatic conditions through the last $\sim 20,000$ years, before going on to compare these results with those from other climatically calibrated archives in the wider East Mediterranean region.

\section{Study Site}

Eski Acıgöl (1270 masl; 38 33'01' 'N, 34 32'41' 'E) is a former crater lake lying within a larger caldera in the Cappadocian region of central Turkey (Figure 1). The caldera, which exposes thick tuffs, volcanic ash, obsidian, ignimbrites and basaltic cones, was formed in the mid-Pleistocene (Druitt et al., 1995). The formerly brackish lake was drained in 1972. The historic lake had no surface inflows or outflows and the surface catchment was never very much larger than the lake itself. Inputs into the lake would have therefore been dominated by direct precipitation and ground water inflows and output by evaporation and ground water seepage. A multi-proxy study of change in the lake system over the last $\sim 20 \mathrm{kyr}$ was carried out on cores taken from the crater (Roberts et al., 2001). A $16 \mathrm{~m}$ core sequence from parallel, overlapping cores (ESK96A/B and ESK97A/B) recovered non-laminated carbonate-rich lake sediments in the upper $6.5 \mathrm{~m}$ spanning the second half of the Holocene, underlain by annually-laminated lake deposits that were formed under relatively deepwater conditions, back to the last glacial maximum (LGM) (Figure 2). 


\section{Lake isotope mass balance}

The hydrological budget of a lake can be explained by the sum of the inflows and outflows from the system (e.g. Gibson et al., 1999; Ricketts and Johnson, 1996), for example:

$$
\mathrm{dV} / \mathrm{dt}=\mathrm{P}+\mathrm{S}_{\mathrm{i}}+\mathrm{G}_{\mathrm{i}}-\mathrm{E}-\mathrm{S}_{\mathrm{o}}-\mathrm{G}_{\mathrm{o}}
$$

where $\mathrm{V}$ is lake volume; $\mathrm{t}$, time; $\mathrm{P}$, precipitation on the lake surface; $\mathrm{S}_{\mathrm{i}}$, surface inflow from rivers and/ or overland runoff; $G_{i}$, ground water inflow; E, evaporation from the lake surface; $S_{o}$, surface outflow; $G_{0}$, ground water outflow. (V, P, $S_{i}, G_{i}, E, S_{o}$ and $G_{o}$ are measured in the same units).

As well as the water balance equation above (equation 1), the stable isotope values of the lake hydrological system must also balance such that:

$$
\mathrm{dV} \delta_{\mathrm{I}} / \mathrm{dt}=\mathrm{P} \delta_{\mathrm{P}}+\mathrm{S}_{\mathrm{i}} \delta_{\mathrm{Si}}+\mathrm{G}_{\mathrm{i}} \delta_{\mathrm{Gi}}-\mathrm{E} \delta_{\mathrm{E}}-\mathrm{S}_{\mathrm{o}} \delta_{\mathrm{So}}-\mathrm{G}_{\mathrm{o}} \delta_{\mathrm{Go}}
$$

where the values $\delta_{\mathrm{l}}, \delta_{\mathrm{p}}, \delta_{\mathrm{Si}}, \delta_{\mathrm{Gi}}, \delta_{\mathrm{E}}, \delta_{\mathrm{So}}, \delta_{\mathrm{Go}}$ are the isotope values (either $\delta^{18} \mathrm{O}$ or $\delta \mathrm{D}$ ) of the lake waters, lake surface precipitation, surface inflow, ground water inflow, lake surface evaporation, surface outflow and ground water outflow respectively (e.g. Benson and Paillet, 2002; Gibson et al., 1999).

\section{Methods}

\section{Analytical methods}

Stable isotope measurements were determined (relative to $\mathrm{PDB}$ ) on $\mathrm{CO}_{2}$ liberated from $10 \mathrm{mg}$ bulk sediment samples of calcium carbonate, reacted in phosphoric acid overnight at $25^{\circ} \mathrm{C}$, using a VG Optima mass spectrometer with analytical errors of $\pm 0.1 \%$. The mineralogical content of the samples was identified using X-ray diffractometry by infrared spectroscopy on a Perkin-Elmer IR-TF/16 PC spectrometer at UMR 8501. Full details of the methods used can be found in Roberts et al. (2001).

\section{Numerical methods}

For any given time period it can be assumed that a lake is at hydrological steady-state, such that equation 2 can be written:

$$
\mathrm{P} \delta_{\mathrm{P}}+\mathrm{S}_{\mathrm{i}} \delta_{\mathrm{Si}}+\mathrm{G}_{\mathrm{i}} \delta_{\mathrm{Gi}}=\mathrm{E} \delta_{\mathrm{E}}+\mathrm{S}_{\mathrm{o}} \delta_{\mathrm{So}}+\mathrm{G}_{\mathrm{o}} \delta_{\mathrm{Go}}
$$


Here we take five periods (designated as Late Holocene, Early Holocene, Late Glacial Stade, Late Glacial Interstade, and Glacial) within the overall Eski Acıgöl isotope stratigraphy where recorded $\delta^{18} \mathrm{O}$ values from calcium carbonate $\left(\delta^{18} \mathrm{O}_{\text {recorded }}\right)$ are relatively constant (Figure 2, Table 1). The two gaps is the $\delta^{18} \mathrm{O}$ record at $\sim 7 \mathrm{~m}$ and $\sim 8 \mathrm{~m}$ are periods of negative isotope excursions (shown in Figure 3 of Roberts et al., 2001) associated with local tephra horizons. These excursions may be due to reactivation of ground waters in the system during periods of volcanic activity and are therefore not included in discussion of climate change.

For each time period we attempt to balance equation 3 and therefore quantitatively understand how climate has changed in central Turkey over the last $\sim 20 \mathrm{kyr}$. This analysis is intended to quantify mean steady-state conditions for different times in the past and not to test for sub-millennial climate variability or for rates of change across major climate transitions. The Glacial period in this sequence is dated between 16 and $\sim 23 \mathrm{ka}$, and probably does not overlap substantially with the period of highest lake levels immediately prior to the LGM in the East Mediterranean region (Bartov et al, 2002; Fontugne et al, 1999; Roberts and Wright, 1993).

Here the term Late Glacial Stade refers to the period of time $(\sim 12.5 \mathrm{ka})$ where $\delta^{18} \mathrm{O}_{\text {recorded }}$ values return to values similar to those during Glacial times, following a late glacial interstadial period when $\delta^{18} \mathrm{O}_{\text {recorded }}$ values were close to those of the early Holocene. These shifts in the lake system occurred at approximately the same time as the Younger Dryas and Bölling-Alleröd events in Northern Europe and are likely to be connected to Northern Hemisphere climate shifts at these times. However, due to the U-series dating uncertainties for the Eski Acıgöl sequence, it is not currently possible to demonstrate climatic synchroneity or formal stage equivalence.

\section{Values for the Eski Acıgöl calculations}

To understand quantitatively each of the five time periods defined above, as many of the parameters as possible in equation 3 must be known. Below each is discussed and values for each time period are prescribed.

Temperature (T): temperature is a key control on many of these parameters and an independent control on temperature is required for input into these calculations. Present-day temperatures in the Cappadocian region are coherent between meteorological stations (Figure 3). Average annual temperatures are between +9 and $+11^{\circ} \mathrm{C}$, summer maximum values are around +28 to $+30^{\circ} \mathrm{C}$ and winter minimum temperatures around -6 to $-8^{\circ} \mathrm{C}$ (based on the two years values shown in Figure 3). It has been proposed elsewhere (Bar-Matthews et al., 2003) that temperature changes in the eastern Mediterranean are coherent on land and at sea. Emeis et al. (2000) reconstruct sea-surface temperatures (SST) for two sites in the Eastern Mediterranean basin through the time period under investigation based on alkenones (Table 1). For the Ionian Sea the total SST difference between glacial and interglacial times was $8^{\circ} \mathrm{C}$, whereas in the Levantine basin there was an inferred temperature change of $6^{\circ} \mathrm{C}$. Hayes et al. (2005) give values for glacial sea-surface temperatures ranging from 
2 to $6^{\circ} \mathrm{C}$ cooler than present day in the Eastern Mediterranean based on planktonic foraminifera assemblages. Average annual temperatures at Eski Acıgöl for the five time periods are based largely on the magnitude of change from the Levantine basin (Table 1) as it is closer to Eski Acıgöl. The changes for the Late Glacial Stade and Late Glacial Interstade, where there are no data from the Levantine basin, are kept within the maximum range from this study as the changes in Ionian Sea SST are considerably larger.

Precipitation (P): modern average annual precipitation (p) in Cappadocia is about $0.36 \mathrm{~m} \mathrm{yr}^{-1}$ (Figure 3) and this will therefore be taken as the value for the Late Holocene period. Although there is variability through all the time periods discussed, within each period the average $\delta^{18} \mathrm{O}_{\text {recorded }}$ value remains relatively constant. A detailed record of the last 2000 years (i.e. the Late Holocene) from a nearby analogous lake, Nar Gölü, shows that mean $\delta^{18} \mathrm{O}_{\text {recorded }}$ for the last 2000 years are close to the mean values for the last 80 years (Jones et al., 2006), suggesting that modern meteorological values and stable isotope hydrological records are probably typical of the late Holocene. Values for the other four time periods are unknown. The amount of precipitation entering the lake is also dependent on lake area.

Lake area (A): the exact lake area for any of the time periods under investigation is unknown. However, simple relationships between lake depth, lake area and lake volume can be developed from the crater morphology (Figure 1). The cores bottomed out in volcanics so a reasonable picture of the basin shape can be established. During the Glacial through to the Early Holocene the lake sediments were laminated and the lake must therefore have been stratified, with anoxic bottom waters. Nearby Nar Gölü is $26 \mathrm{~m}$ deep at its deepest and waters are anoxic below $\sim 10 \mathrm{~m}$. Cores were taken in Nar in the deepest part of the basin and are laminated throughout the last 2000 years (Jones et al., 2006). Cores taken in $15 \mathrm{~m}$ water depth are also laminated throughout this time period, suggesting that the chemocline is permanently above $15 \mathrm{~m}$ water depth in lakes of this type and size. Therefore, we assume that Eski Acıgöl must have been at least $10 \mathrm{~m}$ deep during the Glacial to Early Holocene period. The maximum possible water depth for Eski Acıgöl would be $\sim 30 \mathrm{~m}$ as the lake basin rim is at 1285 metres above sea level (masl) and the lake would have begun to overflow at this point. During the mid-Holocene the lake sediments cease to be laminated indicating that lake levels were significantly reduced. However, lake area may have changed less dramatically as part of this reduction in lake depth is due to sediment infilling the crater. From the core stratigraphy (Figure 2) it is possible to assess the elevation of the lake bed during each of the time periods under investigation. Diatom evidence shows that the Late Glacial water level at Eski Acıgöl was not as high as during the Early Holocene (Roberts et al. 2001) and Late Holocene lake levels were lower than either of these periods. A range of possible lake water depths for each of the time periods can therefore be obtained (Table 2).

Isotopic composition of rainfall $\left(\delta_{\mathrm{P}}\right)$ : There is a classic Dansgaard relationship between temperature and $\delta_{\mathrm{P}}$ for contemporary rain waters on the Anatolian Plateau, with temperature positively correlated with $\delta_{\mathrm{P}}$ values in Ankara $\left(\delta^{18} \mathrm{O}_{\mathrm{P}}[\mathrm{SMOW}]=0.31 \mathrm{~T}_{\max }-13.2 ; \mathrm{r}^{2}=0.64 ; \mathrm{IAEA} / \mathrm{WMO}, 2001\right)$. If this relationship holds back through time, then $\delta_{\mathrm{P}}$ values would have been more negative during glacial times. For example, a shift of $6^{\circ} \mathrm{C}$ 
would decrease $\delta^{18} \mathrm{O}_{\mathrm{P}}$ by $1.8 \%$ compared to today, based on the equation above. However, there would have been additional changes in $\delta_{\mathrm{P}}$ as glacial ocean waters, from which rain/snowfall is derived, would have been substantially more positive than during interglacial times due to the preferential storage of ${ }^{16} \mathrm{O}$ in the ice caps. Emeis et al. (2000) show that $\delta^{18} \mathrm{O}$ values from planktonic foraminifera were $2.9 \%$ more positive during glacial times in the Ionian Sea and 3.8\% more positive in the Levantine basin. However, because these values are also dependent on temperature changes, the values must be corrected by $0.2 \%$ o $/{ }^{\circ} \mathrm{C}$ (Emeis et al., 2000). Corrected values of change between glacial and interglacial times for $\delta^{18} \mathrm{O}$ values of the Mediterranean Sea waters would therefore be approximately $+1.3 \%$ for the Ionian Sea and $+2.8 \%$ for the Levantine Basin. The combined effect of the temperature and source water effect would therefore be between -0.5 and $+1 \%$ for the difference between Late Glacial and Holocene $\delta_{\mathrm{P}}$ values. $\delta^{18} \mathrm{O}$ values of Mediterranean Sea water decrease incrementally between the Glacial and Holocene (Emeis et al., 2000) and prescribed values for Late Glacial Interstade and Stade $\delta_{\mathrm{P}}$ therefore change accordingly (Table 4).

Surface inflow (Si): Due to the small area of the catchment compared to lake area, surface inflow is assumed to be 0 .

Ground water inflow (Gi): The amount of ground water inflow into the lake is unknown for any of the time periods.

Isotopic composition of ground water inflow $\left(\delta_{\mathrm{Gi}}\right)$ : Ground waters entering the lake are taken to have the same isotope value as mean weighted precipitation because contemporary ground waters in the region have been shown to be meteoric (Jones et al., 2005; Roberts et al., 2001).

Evaporation (E): Evaporation can be calculated, for example, using equation 4 (Linacre, 1992):

$$
E=\left[0.015+4 \times 10^{-4} T_{a}+10^{-6} z\right] \times\left[480\left(T_{a}+0.006 z\right) /(84-L a t)-40+2.3 u\left(T_{a}-T_{d}\right)\right]
$$

where $\mathrm{E}=$ Evaporation $\left(\mathrm{mm}\right.$ day $\left.^{-1}\right), \mathrm{T}_{\mathrm{a}}=$ average air temperature $\left({ }^{\circ} \mathrm{C}\right), \mathrm{z}=$ altitude $(\mathrm{m})$, Lat $=$ latitude, $\mathrm{u}=$ wind speed $\left(\mathrm{m} \mathrm{s}^{-1}\right)$ and $\mathrm{T}_{\mathrm{d}}=$ dew point temperature $=0.52 \mathrm{~T}_{\min }+0.60 \mathrm{~T}_{\max }-0.009\left(\mathrm{~T}_{\max }\right)^{2}-2{ }^{\circ} \mathrm{C}, \mathrm{T}_{\min }=$ minimum temperature, $T_{\max }=$ maximum temperature. Minimum and maximum temperatures are assumed to shift by the same magnitude as $T_{a}$ (Table 1). Late Holocene values are $T_{a}=10, T_{\min }=5, T_{\max }=15.5$ (Figure $3)$.

Equation 4 has been used to calculate evaporation for the five time periods investigated here, since this equation has been shown to produce values close to contemporary measured evaporation across Turkey (Jones et al., 2005). Based on colder temperatures, evaporation would have been much lower during glacial times; however, there is no way of calculating wind speeds. Contemporary wind speeds on the Anatolian Plateau average about $3 \mathrm{~m} \mathrm{~s}^{-1}$ during the year (Meteoroloji Bülteni, 1974; field observations). If wind speeds 
were higher during glacial times, which has been suggested (e.g. Wyputta and Grieger, 1999), evaporation would increase. However, sensitivity analysis of evaporation with changing wind speed (Figure 4a) shows that average glacial wind speeds would have to be greater than $26.5 \mathrm{~m} \mathrm{~s}^{-1}$ for evaporation to be higher during the late glacial compared to the late Holocene. For the Holocene and Late Glacial Interstadial periods wind speeds are taken to be $3 \mathrm{~m} \mathrm{~s}^{-1}$, and wind speeds are arbitrarily taken to be twice as strong $\left(6 \mathrm{~m} \mathrm{~s}^{-1}\right)$ during the Late Glacial and Late Glacial Stadial periods. With these values of wind speed and the given values of temperature Late Holocene evaporation is taken to be $1.08 \mathrm{~m} \mathrm{yr}^{-1}$ which is within the range of recorded evaporation across Turkey (Meteoroloji Bülteni, 1974), compared to values of $0.40 \mathrm{~m} \mathrm{yr}^{-1}$ during the Glacial.

Isotopic composition of Evaporation $\left(\delta_{\mathrm{E}}\right)$ : An equation for calculating $\delta_{\mathrm{E}}$ was obtained from observations at Pyramid Lake, Nevada (Benson and White, 1994), and has been used by other authors for modelling other sites (e.g. Ricketts and Johnson, 1996). It states that:

$$
\mathbf{R}_{\text {evap }}=\left[\left(\mathbf{R}_{\text {lake }} / \alpha_{\text {eq }}\right)-\left(\mathrm{RH} f_{a d} \mathbf{R}_{\text {at }}\right)\right] /\left[\left((1-\mathrm{RH}) / \alpha_{\text {kin }}\right)+\mathrm{RH}\left(1-f_{a d}\right)\right]
$$

where $\delta_{\mathrm{i}}=\left(\mathbf{R}_{\mathrm{i}}-1\right) 10^{3}, \mathbf{R}_{\mathrm{at}}$ is the isotope ratio of the free atmospheric water vapour, $f_{a d}$ is the fraction of atmospheric water vapour in the boundary layer over the lake (if all the atmospheric water overlying the lake is derived from evaporation, then $\left.f_{a d}=0\right)$, RH is the relative humidity, and $\alpha_{\mathrm{eq}}\left(1 / \alpha^{*}\right)$ and $\alpha_{\mathrm{kin}}$ are fractionation factors.

Fractionation factors $\left(\boldsymbol{\alpha}_{\mathrm{eq}}\right.$ and $\left.\boldsymbol{\alpha}_{\mathrm{kin}}\right)$ : the equilibrium fractionation factor, $\alpha_{\mathrm{eq}}$, can be calculated

$$
\alpha_{\mathrm{eq}}=\exp \left(1137 \mathrm{~T}^{-2}-0.4156 \mathrm{~T}^{-1}-2.0667 \times 10^{-3}\right)=1 / \alpha^{*}
$$

where $\mathrm{T}$ is the temperature of the lake surface water in degrees Kelvin. The kinetic fractionation factor, $\alpha_{\text {kin, }}$ is dependent on wind speed and for wind speeds less than $6.8 \mathrm{~m} \mathrm{~s}^{-1}, \alpha_{\mathrm{kin}}=0.994$ (Majoube, 1971).

Fraction of atmospheric water vapour $\left(\boldsymbol{f}_{a d}\right)$ : Benson and White (1994) suggest that $f_{a d}$ should always be taken as 0 as the water vapour immediately overlying the liquid surface will be the dominant control on $\delta_{\mathrm{E}}$ and will be almost entirely made up of evaporated water. This assumption will be used here.

Isotope value of atmospheric water vapour $\left(\delta^{18} \mathbf{O}_{a t}\right)$ : because $f_{a d}$ is assumed to be 0 the value of $\delta^{18} \mathrm{O}_{a t}$ does not influence $\delta_{\mathrm{E}}$ and is therefore not required.

Relative humidity (RH): relative humidity has a strong relationship with temperature and rainfall in contemporary Cappadocia (Jones et al., 2005) with increasing RH associated with decreased temperatures, as the volume of air holding a given mass of water decreases, and increased rainfall. However, over glacialinterglacial time scales it has been suggested that increases in temperature have been associated with 
increases in relative humidity as more moisture becomes available and more is evaporated (Lemke and Sturm, 1997). Previous work in Eastern Turkey (Lemcke and Sturm, 1997) suggests that glacial relative humidity was around 35 to $40 \%$ during the last glaciation rising to around $60 \%$ in the Early Holocene. In this study Holocene values for RH are taken as $68 \%$, based on annual average values for Cappadocia (Figure 3). Glacial values are taken to be $40 \%$ based on the work of Lemcke and Sturm (1997). Instrumental records show that RH values in Van and Cappadocia are similar at the present day (Meteoroloji Bülteni, 1974).

Surface outflow $\left(\mathbf{S}_{\mathbf{0}}\right)$ : Surface outflow from the lake would occur only if the lake level rose by more than $\sim 30 \mathrm{~m}$, at which point it would overflow.

Ground water outflow $\left(\mathbf{G}_{\mathbf{0}}\right)$ : Ground water output from the lake is unknown.

Isotopic value of ground water $\left(\delta_{G_{0}}\right)$ : Ground water leaving the lake is taken to be isotopically the same as lake water values $\left(\delta_{1}\right)$.

Isotopic value of lake water $\left(\delta_{1}\right)$ : Figure 2 shows the $\delta^{18} \mathrm{O}_{\text {recorded }}$ data from the Eski Acigöl core sequence. Before these values can be used in the calculations they must be corrected for fractionation differences due to the different types of calcium carbonate precipitated and converted to values of $\delta_{1}$. Taking the mineralogy data from Figure 2, Early Holocene carbonates are predominantly calcite and therefore $\delta^{18} \mathrm{O}_{\text {recorded }}$ can remain unchanged. Glacial isotope values are recorded from sediments comprised largely of aragonite and a correction factor of $-0.6 \%$ (Tarutani et al., 1965) must therefore be applied. In addition some of the Late Holocene sediments comprise authigenic dolomite which is $\sim 3 \%$ more positive relative to calcite precipitated under the same conditions (Land, 1980). Some of these Late Holocene sediments also contain aragonite. The Late Holocene values can be corrected to calcite if the amount of the three different carbonates is known as:

$$
\delta^{18} \mathrm{O}_{\text {recorded }}=f_{\text {calcite }} \delta^{18} \mathrm{O}_{\text {calcite }}+f_{\text {aragonite }}\left(\delta^{18} \mathrm{O}_{\text {calcite }}+0.6\right)+f_{\text {dolomite }}\left(\delta^{18} \mathrm{O}_{\text {calcite }}+3\right)
$$

where $f_{\text {calcite }}, f_{\text {aragonite }}, f_{\text {dolomite }}$, are the fraction of each mineral phase in the sediment. However, it is unlikely that all the dolomite is reacted during the isotope analysis procedure used here and that the real calciteequivalent value of the analysed sediments is therefore somewhere between the recorded value and that calculated from equation 7. (For the sensitivity of the Late Holocene calculations to these different values see below). Initially a correction of $-0.6 \%$ will be used to account for some of the difference due to dolomite and the part of the Late Holocene curve where aragonite is present.

Carbonates are generally precipitated in the summer months (Saarnisto, 1986; Jones et al., 2005) and summer temperature is therefore used to calculate the $\delta_{1}$ values from which the carbonates were precipitated. Nar Gölü, a contemporary analogue for Eski Acıgöl, has lake water temperatures that lie between the 
monthly average and maximum values, and therefore an average of these values are used to calculate the lake water temperatures from which the carbonates are precipitated, using the equation of Kim and O'Neil (1997) modified by Leng and Marshall (2004) (equation 8). It has been suggested (Leng and Marshall, 2004) that this equation be used for all calculations although temperatures calculated from it are lower than those using some other palaeotemperature equations (e.g. Anderson and Arthur, 1983) and the validity of the Kim and O'Neil equation has been questioned (Zhou and Zheng, 2003).

$$
\mathrm{T}=13.8-4.58(\delta \mathrm{c}-\delta \mathrm{w})+0.08(\delta \mathrm{c}-\delta \mathrm{w})^{2}
$$

where $\mathrm{T}$ is the lake water temperature $\left({ }^{\circ} \mathrm{C}\right), \delta \mathrm{c}$ is the calcite equivalent $\delta^{18} \mathrm{O}$ value relative to VPDB and $\delta \mathrm{w}$ is the unknown isotope value of the lake water relative to VSMOW. Changes in summer temperatures are based on the magnitude of change for average temperatures in Table 1. Late Holocene values for Eski Acıgöl are $17^{\circ} \mathrm{C}$ for average summer temperature and $24.5^{\circ} \mathrm{C}$ for maximum summer temperatures (Figure 3). Based on these values lake water isotope values can be calculated for the time periods under investigation (Table $3)$.

\section{Model sensitivity}

Sensitivity tests look at the possible variability and errors that may have occurred in the original calculations. For this a range of lake depths are used (Table 2). Three other input variables can be easily changed, values for relative humidity, wind speed and temperature have been prescribed for all times periods except the Late Holocene. By changing these values it is possible to observe if the initial values, and relative states, are robust or sensitive to changes in these parameters.

The effect of changing values of wind speed (Figure 4a) have been discussed above and make very little difference to the ranges of values calculated relative to changes in temperature. Temperature values were changed by $\pm 1^{\circ} \mathrm{C}$ for each of the time periods to see how sensitive the equations are to changes in temperature and to allow for errors in the temperature estimates. Relative humidity controls changes in $\delta_{\mathrm{E}}$, and it is taken into account in calculations of $E$ in the form of $T_{d}$ which is estimated from $T_{\min }$ and $T_{\max }$. Figure $4 \mathrm{~b}$ shows the sensitivity of $\delta_{\mathrm{E}}$ to changing RH at different values of $\delta_{1}$. Given the large differences in $\delta_{1}$ prescribed by $\delta^{18} \mathrm{O}_{\text {recorded }}$, $\delta_{\mathrm{E}}$ is not sensitive enough to changing $\mathrm{RH}$ to have a large impact on the model output.

\section{Results}

Based on the values above, equation 3 can be balanced for the five time periods of interest; Late Holocene, Early Holocene, Late Glacial Stade, Late Glacial Interstade, Glacial (Table 4). Unknowns in equation 3 can be investigated by simultaneously solving isotope mass balance equations (i.e. equation 3 ) with a steady- 
state water mass balance version of equation 1. This results in all values being known for the Late Holocene, as there are only two unknowns, $G_{i}$ and $G_{0}$. For the four other time periods there are three unknowns.

However, equation 3 can be expressed:

$$
\delta_{\mathrm{P}}\left(\mathrm{P}+\mathrm{G}_{\mathrm{i}}\right)=\mathrm{E} \delta_{\mathrm{E}}+\mathrm{G}_{\mathrm{o}} \delta_{1}
$$

where if $(P+G i)=Q i$, the total influx into the lake, there are again only two unknowns $\left(Q_{i}\right.$ and $\left.G_{o}\right)$, which can therefore be calculated.

As discussed above the exact calcite-equivalent isotope value for the Late Holocene is unknown due to the presence of dolomite in the sediment. The actual value will lie somewhere between the value used and the value calculated using equation 6 ; that is, between +1 and $+2 \%$. As the calculations from equation 3 show that ground water outflow from the lake must be 0 at this time the lake hydrological budget is simply Q $\mathrm{i}=\mathrm{E}$ where $\mathrm{P}$ and $\mathrm{E}$ are both known. $\mathrm{G}_{\mathrm{i}}$ can therefore be easily calculated. It therefore makes no difference to the calculation which value of $\delta_{1}$ is used, as neither $\delta_{1}$ nor $\delta_{\mathrm{E}}$ are used in the calculation.

From the five solutions to equation 9 it can be shown that there is larger water input into the lake during the Early Holocene and the Late Glacial Interstade than at any other times during the record (5.2-7.2 and 4.2-6.4 $x 10^{5} \mathrm{~m}^{3}$ respectively, table 4), with the Glacial being the time of least water input into the lake system $(<2.7$ $\left.\mathrm{x} 10^{5} \mathrm{~m}^{3}\right)$.

\section{Calculating precipitation}

There are clear differences between the values for total water influx (Qi) between the five time periods (Table 4). Investigating the controls on this value can lead to an understanding of how precipitation may have varied in the past. The amount of precipitation (p) will be important in controlling Qi, as well as parameters controlling the fraction of water falling in the lake catchment which reaches the lake as groundwater inflow. However, apart from $\mathrm{p}$ there are only a few factors that could significantly change the amount of water reaching the lake through ground water in this small catchment. Pollen evidence from the region shows that arboreal vegetation re-established itself relatively slowly in central and eastern Turkey during the Holocene (Wick et al., 2003; Woldring and Bottema, 2003), so it is unlikely that Early Holocene and glacial-age woody vegetation made a major difference to evapotranspiration rates. Although it was significantly colder in Turkey during glacial times, and the lake is likely to have frozen in winter, it is unlikely that there was significant freezing of the ground water system throughout the year. The main controlling factor on the volume of water entering the lake must therefore have been $p$.

From these calculations it is possible to conclude that precipitation was lower in central Turkey at, and after, the LGM compared to the Early Holocene, and that the latter period was wetter than the present day. 
Additionally, it is possible to refine further the data and investigate how these changes in water balance may reflect changes in climate conditions.

The value of $\mathrm{p}$ is known for the Late Holocene; however, modelled values of Qi vary with different prescribed lake areas and temperatures. To calculate precipitation in the past a relationship for $\mathrm{p}$ as a function of Qi needs to be established. From the late Holocene model solved for a range of temperature and lake area conditions:

$$
\mathrm{p}=\mathrm{Qi} / 3.4 \mathrm{~A}
$$

Equation 10 gives a value of $0.32 \pm 0.04 \mathrm{~m} \mathrm{yr}^{-1}$ for Late Holocene precipitation, consistent with instrumentally recorded $p$ in the region (Figure 3). From equation 10 and the calculations of Qi precipitation during the Early Holocene was $0.39 \pm 0.06 \mathrm{~m} \mathrm{yr}^{-1}$ and precipitation values were $0.24 \pm 0.06 \mathrm{~m} \mathrm{yr}^{-1}$ during the Late Glacial Stade, $0.45 \pm 0.05 \mathrm{~m} \mathrm{yr}^{-1}$ during the Late Glacial Interstade and $0.20 \pm 0.07 \mathrm{~m} \mathrm{yr}^{-1}$ during the Glacial (Figure 5).

\section{Controls on regional lake isotope values}

These calculations also allow investigation of the controls on $\delta_{1}$ values in the East Mediterranean region. The Eski Acıgöl record was initially interpreted to reflect a change in the precipitation: evaporation (P:E) ratio (Roberts et al., 2001). Using values from these five time periods it can be shown that the interpretation cannot be this simple. Although for the two Holocene periods more negative $\delta^{18} \mathrm{O}_{\text {recorded }}$ values are associated with a higher P:E ratio, the highest P:E ratio occurred during the Glacial which has intermediate $\delta^{18} \mathrm{O}_{\text {recorded }}$ values. Other possible controls on the lake system can be investigated by comparing the calcite equivalent carbonate isotope value $\left(\delta^{18} \mathrm{O}_{\text {calcite }}=\delta^{18} \mathrm{O}_{\text {recorded }}\right.$ corrected for changes in mineralogy) with other parameters (Table 5). From this it can be shown that the strongest correlation is between $\delta^{18} \mathrm{O}_{\text {calcite }}$ and lake depth $\left(r^{2}=0.63\right)$ or water volume $\left(r^{2}=0.65\right) . G_{o}$ also has a strong correlation with $\delta^{18} \mathrm{O}_{\text {recorded }}\left(r^{2}=0.57\right)$. This suggests that it is the volumetric flux of water passing through the lake that controls $\delta_{1}$ rather than P:E per se, and that the amount of ground water outflow relative to E may also be significant.

\section{Regional comparisons}

Further evidence of Late Quaternary hydrological variability on the Anatolian plateau comes from studies of past lake levels on the Konya plain $\sim 150 \mathrm{~km}$ to the southwest of Cappadocia (Figure 1). Palaeo-lake Konya contrasts sharply with the Eski Acıgöl crater lake in having been large and shallow relative to its surface area, and dominated by runoff and direct precipitation. Lake-level reconstructions show that a mega-lake existed at and prior to the LGM (Roberts, 1983) and also show that the Late Glacial Interstade was probably the only time when substantial permanent standing water bodies existed on the Konya plain after $\sim 20$ ka. 
During the post-LGM Glacial, Late Glacial Stade and Holocene the Konya basin was generally dry with the establishment and re-activation of aeolian dune systems (Kuzucuoğlu et al., 1998; Fontugne et al., 1999). These data are consistent with the sequence of precipitation changes inferred from the Eski Acigöl isotope record. As the last major lake high-stand in the Konya basin occurred at and prior to $\sim 21$ ka (Roberts, 1983), precipitation must therefore have been higher at that time than between 21-16 ka, unless temperatures, and therefore evaporation rates, were also significantly lower. There were, therefore, cold and wet periods ( $>21$ $\mathrm{ka})$, as well and cold and dry periods $(21-16 \mathrm{ka})$ in the Eastern Mediterranean during the last glaciation. Given that the calculations from Eski Acıgöl show warm and dry as well as warm and wet Holocene conditions, there can be no simple relationship between changes in temperature and moisture in the region over glacial-interglacial timescales.

The lake-level record from Lake Van in eastern Anatolia (Figure 1) also shows impressive variations through the time frame under investigation here, with evident similarities to the sequences from Eski Acigöl and Konya. Landmann et al. (1996) showed that, as in Konya, the pre-LGM $(<21 \mathrm{ka})$ was a period of lake highstand. The maximum high-stands in the lakes of the Jordan rift valley similarly preceded the LGM (Hazan et al., 2005; Bartov et al., 2002) with lake levels apparently falling before the main LGIT temperature amelioration (c. $14 \mathrm{ka}$ ). In Van, there was a drop in lake level of $>200 \mathrm{~m}$ during the post-LGM Glacial when much of the lake bed was dry. As at Konya and Eski Acıgöl, lake levels rose here during the Late Glacial Interstade, before falling again during the Late Glacial Stade. Maximum postglacial lake levels were reached during the first half of the Holocene, although later than the apparent precipitation maximum in the lake sites of west-central Anatolia.

Further south, Bar-Matthews et al. (1997; 2003) have reconstructed precipitation variability over the same time period covered by the Eski Acıgöl record from Soreq Cave in Israel. The stable isotope data from the Soreq speleothems provides an obvious point of comparison with the climatically calibrated lake isotope record from central Anatolia. For comparison between the two data sets, we have calculated the values of palaeo-precipitation at Soreq using the same amplitude temperature changes prescribed in the Eski Acıgöl time frames, and for similar time periods where $\delta^{18} \mathrm{O}_{\text {recorded }}$ values from the Soreq Cave are generally constant, assuming that major isotope changes were broadly synchronous between the two sites. Late Holocene average $\delta^{18} \mathrm{O}_{\text {recorded }}$ values at Soreq are $-5.3 \%$, compared to $-6.1 \%$ for the Early Holocene, $-4.3 \%$ o for the Late Glacial Stade, $-5.8 \%$ for the Late Glacial Interstade and $-3.1 \%$ for the Glacial (McGarry et al., 2004). The isotope values of cave waters, which are $1 \%$ enriched in ${ }^{18} \mathrm{O}$ compared to rainfall (Bar-Matthews et al., 2003), appear to be controlled by the amount of precipitation with more positive isotope values associated with reduced rainfall. Past values of cave waters are calculated from the values of speleothem carbonate and the same amplitude temperature shifts used for the Eski Ac1göl calculations, using equation 7.

As shown in Figure 5, the long-term trends of precipitation in both central Turkey and northern Israel are remarkably similar. Being located in what is today a wetter climatic region, reconstructed precipitation 
values at Soreq Cave are, not surprisingly, consistently higher than those at Eski Acigöl. Additionally, these results suggest that the effect of the Late Glacial Stade was felt more strongly in the interior location of Eski Acıgöl than at Soreq Cave, near to the Mediterranean coast, with either a greater reduction in precipitation or temperature changes of different amplitude at the two sites during this time period, or both.

During the Late Glacial Stade, Lake Van showed a shift in $\delta^{18} \mathrm{O}_{\text {recorded }}$ values even larger $(\sim 5 \%)$ than that at Eski Acıgöl (2.5\%) (Wick et al., 2003). As Van is a much larger lake than Eski Acıgöl, and with more evaporated lake waters, the same climatic forcing would be expected to produce a smaller isotopic response at Van (Leng and Marshall, 2004). The larger shift in $\delta^{18} \mathrm{O}_{\text {recorded }}$ at Van therefore suggests that the Late Glacial Stade was more pronounced here than in central Anatolia, which in turn was more marked than in the southern Levant. This implies that a steeper moisture gradient may have existed between coastal and interior parts of the East Mediterranean during Late Glacial Stadial times than at the present day.

\section{Conclusions}

A $\delta^{18} \mathrm{O}_{\text {recorded }}$ record from Eski Acıgöl crater lake confirms that the post-LGM Glacial period was characterised by lower precipitation as well as having lower temperatures than today, and that the Early Holocene was wetter than at present. Through isotope and hydrological mass balance modelling we have been able to quantify this change in terms of specific climate variables for the first time in Turkey. PostLGM Glacial precipitation in central Turkey was $\sim 60 \%$ lower than the present day value, but $\sim 20 \%$ higher during the Early Holocene. These long-term trends are similar to those recorded at Soreq Cave in central Israel, suggesting a coherency in climate across this region. Palaeo-precipitation values are dependent on prescribed temperature values and may therefore change with improved future understanding, particularly of spatial variability in terrestrial temperature trends across the Eastern Mediterranean. Importantly, we have shown that there were periods of cold-dry climate and cold-moist climate within the last glacial, as well as periods of warm-wet and warm-dry climate during the Holocene.

\section{Acknowledgements}

This work was carried out whilst MDJ was funded by the Leverhulme Trust (F/00568/1). We would like to thank Miryam Bar-Matthews for discussion of the Soreq cave data and interpretations. We would also like to thank Warren Eastwood, Emma Jenkins, Arlene Rosen and Rebecca Turner and for discussions on the early drafts of this work. Tim Absalom and Jamie Quinn are thanked for the drafting of some of the figures. We also acknowledge the contribution of the colleagues who collected and analysed the Eski Acigöl sequence (Roberts et al., 2001). We are extremely grateful to Avner Ayalon, Yuval Bartov, Jay Quade and an anonymous reviewer for detailed reviews and comments which greatly improved the quality of the manuscript. 


\section{References}

Anderson, T.F. and Arthur, M.A., 1983. Stable isotopes of oxygen and carbon and their application to sedimentological and palaeoenvironmental problems. In: Arthur, M.A., Anderson, T.F., Kaplan, J.R., Veizer, J. and Land L.S. (Eds.), Stable Isotopes in sedimentary Geochemistry: Society of Economic Palaeontologists and Mineralogists Short Course, Vol. 10.

Ariztegui, D., Asioli, A., Lowe, J.J., Trincardi, F., Vigliotti, L., Tamburini, F., Chondrogianni, C., Accorsi, C.A., Mazzanti, M.B., Mercuri, A.M., van der Kaars, S., McKenzie, J.A. and Oldfield, F., 2000. Palaeoclimate and the formation of sapropel S1: inferences from Late Quaternary lacustrine and marine sequences in the central Mediterranean region. Palaeogeography, Palaeoclimatology, Palaeoecology 158, 215-240.

Bar-Matthews M., Ayalon, A., Gilmore, M., Matthews, A. and Hawkesworth, C.J., 2003. Sea-land oxygen isotope relationships from planktonic foraminifera and speleothems in the Eastern Mediterranean region and their implications for paleorainfall during interglacial intervals. Geochemica et Cosmochimica Acta 67, 3181-3199.

Bar-Matthews, M., Ayalon, A., and Kaufman, A., 1997. Late quaternary paleoclimate in the eastern Mediterranean region from stable isotope analysis of speleothems at Soreq Cave, Israel. Quaternary Research 47, 155-168.

Bartov, Y., Stein, M., Enzel, Y., Agnon, A. and Reches, Z., 2002 Lake levels and sequence stratigraphy of Lake Lisan, the late Pleistocene precursor of the Dead Sea. Quaternary Research 57, 9-21

Bartov, Y., Goldstein, S.L., Stein, M. and Enzel, Y. 2003. Catastrophic arid episodes in the Eastern Mediterranean linked with the North Atlantic Heinrich events. Geology 31, 439-442.

Benson, L and Paillet, F., 2002. HIBAL: a hydrologic-isotopic-balance model for application to paleolake systems. Quaternary Science Reviews 21, 1521-1539.

Benson, L. V. and White, J. W. C., 1994. Stable isotopes of oxygen and hydrogen in the Truckee RiverPyramid Lake surface-water system. 3. Source of water vapor overlying Pyramid Lake. Limnology and Oceanography 39, 1954-1958.

Druitt, T.H., Brenchley, P.J., Gökten, Y.E., and Francaviglia, V. 1995. Late Quaternary rhyolitic eruptions from the Acigöl complex, central Anatolia. Journal of the Geological Society of London 152, 655-667. 
El-Moslimany, A., 1984. Comment on Roberts, N. "Age, palaeoenvironments and climatic significance of Late Pleistocene Konya lake, Turkey". Quaternary Research, 21, 115-116.

Emeis, K. C., Struck, U., Schulz, H. M., Rosenberg, R., Bernasconi, S., Erlenkeuser, H., Sakamoto, T., and Martinez-Ruiz, F., 2000. Temperature and salinity variations of Mediterranean Sea surface waters over the last 16,000 years from records of planktonic stable oxygen isotopes and alkenone unsaturation ratios. Palaeogeography Palaeoclimatology Palaeoecology 158, 259-280.

Fontugne, M., Kuzucuoğlu, C., Karabıyıkoğlu, M., Hatte, C. and Pastre, J.-F., 1999. From Pleniglacial to Holocene: a C-14 chronostratigraphy of environmental changes in the Konya Plain, Turkey. Quaternary Science Reviews 18, 573-591.

Gibson, J.J., Edwards, T.W.D. and Prowse, T.D., 1999. Pan-derived isotopic composition of atmospheric water vapor and its variability in northern Canada. Journal of Hydrology 217, 55-74.

Harrison, S.P. and Digerfeldt, G. (1993) European lakes as palaeohydrological and palaeoclimatic indicators, Quaternary Science Reviews 12, 233-248.

Hayes, A., Kucera, M., Kallel, N., Sbaffi, L. and Rohling, E.J., 2005. Glacial Mediterranean sea surface temperatures based on planktonic foraminiferal assemblages. Quaternary Science Reviews 24, 999-1016.

Hazan, N., Stein, M., Agnon, A., Nadel, D., Negendank, J.F.W., Schwag, M.J. and Neev, D. 2005. The late Quaternary limnological history of Lake Kinneret (Sea of Galilee), Israel. Quaternary Research 63, 60-77.

IAEA/WMO, 2001. Global Network of Isotopes in Precipitation. The GNIP Database. Accessible at: http://isohis.iaea.org

Jones, M.D., Leng, M.J. Roberts, C.N. Türkeş, M and Moyeed, R. 2005. A coupled calibration and modelling approach to the understanding of dry-land lake oxygen isotope records. Journal of Paleolimnology 34, 391-411.

Jones, M.D., Roberts, C.N., Leng, M.J. and Türkeş, M. 2006. A high-resolution late Holocene lake isotope record from Turkey and links to North Atlantic and monsoon climate. Geology 34, 361-364.

Kim, S-T and O'Neil, J.R., 1997. Equilibrium and nonequilibrium oxygen isotope effects in synthetic carbonates. Geochimica et Cosmochimica Acta 61, 3461 - 3475. 
Kuzucuoğlu, C., Parish, R., and Karabiyikoğlu, M., 1998. The dune systems of the Konya Plain (Turkey): their relation to environmental changes in Central Anatolia during the Late Pleistocene and Holocene. Geomorphology 23, 257 - 271.

Land, L.S., 1980. The isotopic and trace element geochemistry of dolomite: the state of the art. In: Zenger, D.H (ed.), Concepts and models of dolomitisation. SEPM Special Publication 28, 87-110.

Landmann, G., Reimer, A., and Kempe, S., 1996. Climatically induced lake level changes at Lake Van, Turkey, during the Pleistocene/Holocene transition. Global Biogeochemical Cycles 10, 797-808.

Lemke, G. and Sturm, M., 1997. $\delta^{18} \mathrm{O}$ and trace element Measurements as Proxy for the Reconstruction of Climate Changes at Lake Van (Turkey): Preliminary Results. In: Dalfes, N.D. (ed.) Third Millennium BC Climate Change and Old World Collapse, NATO ASI Series. 149.

Leng, M.J. and Marshall, J.D., 2004. Palaeoclimate interpretation of stable isotope data from lake sediment archives. Quaternary Science Reviews 23, 811-831.

Linacre, E 1992. Climate Data and Resources: A Reference and Guide. Routledge, London 366 pp.

Majoube, F. 1971. Fractionnement en oxygène-18 et un deutérium entre l'eau et sa vapeur. Journal of Chemical Physics 187, 1423-1436.

McGarry, S., Bar-Matthews, M., Matthews, A., Vaks, A., Schilman, B. and Ayalon, A., 2004. Constraints on hydrological and paleotemperature variations in the Eastern Mediterranean region in the last 140ka given by the $\delta \mathrm{D}$ values of speleothem fluid inclusions. Quaternary Science Reviews 23, 919-934.

Meteoroloji Bulteni, 1974. Devlet Meteoroloji Işleri Genel Müdürlüğü (State Meteorological Services), Ankara.

Prentice, I.C., Guiot, J. and Harrison, S.P., 1992. Mediterranean vegetation, lake levels and palaeoclimate at the Last Glacial Maximum. Nature 360, 658-60.

Ricketts, R.D. and Johnson, T.C., 1996. Climate change in the Turkana basin as deduced from a 4000 year long $\delta^{18} \mathrm{O}$ record. Earth and Planetary Science Letters 142, 7-17.

Roberts, N., 1983. Age, palaeoenvironments and climatic significance of Late Pleistocene Konya Lake, Turkey. Quaternary Research 19, 154-171. 
Roberts, N. and Wright, H.E. Jr., 1993. Vegetational, lake-level and climatic history of the Near East and Southwest Asia. In: H.E. Wright, Jr., J.E. Kutzbach, T. Webb III, W.F. Ruddiman, F.A. Street-Perrott and P.J.Bartlein (eds.) Global climates since the last glacial maximum. Minneapolis, University of Minnesota Press. pp.194-220.

Roberts, N., Reed, J., Leng, M.J., Kuzucuoğlu, C., Fontugne, M., Bertaux, J., Woldring, H., Bottema, S., Black, S., Hunt, E. and Karabıyıkoğlu, M., 2001 The tempo of Holocene climatic change in the eastern Mediterranean region: new high-resolution crater-lake sediment data from central Turkey. The Holocene 11, 721-736.

Robinson, S.A., Black, S., Sellwood, B.W. and Valdes, P.J. 2006. A review of palaeocliamtes and palaeoenvironments in the Levant and Eastern Mediterranean from 25,000 to 5000 years BP: setting the environmental background for the evolution of human civilisation. Quaternary Science Reviews 25, 15171541.

Saarnisto, M., 1986. Annually laminated sediments. In: Berglund, B.E. (ed.) Handbook of Holocene Palaeoecology and Palaeohydrology Wiley, Chichester, UK.

Stein, M. 2001 The sedimentary and geochemical record of Neogene-Quaternary water bodies in the Dead Sea Basin - Inferences for the regional paleoclimatic history. Journal of Paleolimnology 26, 271-282.

Tarutani, T., Clayton, R.N. and Mayeda, T.K., 1965. The effect of polymorphism and magnesium substitution on oxygen isotope fractionation between calcium carbonate and water. Geochimica et Cosmochimica Acta 33, 987-996.

van Zeist, W. and Bottema, S., 1991 Late Quaternary vegetation of the Near East. Beihefte zum Tübinger Atlas des Vorderen Orients, Reihe A18, Dr L. Reichert Verlag, Wiesbaden, 156 pp.

Wasylikowa, K. 2005 Palaeoecology of Lake Zeribar, Iran in the Pleniglacial, Late Glacial and Holocene reconstructed from plant macrofossils. The Holocene 15, 720-735.

Wick, L., Lemcke, G. and Sturm, M., 2003. Evidence of Late glacial and Holocene climatic change and human impact in eastern Anatolia: high-resolution pollen, charcoal, isotopic and geochemical records from the laminated sediments of Lake Van, Turkey. The Holocene 13, 665-675.

Woldring, H. and Bottema, S., 2003. The vegetation history of East-Central Anatolia in relation to archaeology: the Eski Acıgöl pollen evidence compared with the Near Eastern environment. Palaeohistoria 43/44, 1-34. 
Wyputta, U., and Grieger, B., 1999. Comparison of eastern Atlantic atmospheric trajectories for present day and last glacial maximum. Palaeogeography Palaeoclimatology Palaeoecology 146, 53-66.

Zhou, G-T and Zheng, Y-F., 2003. An experimental study of oxygen isotope fractionation between inorganically precipitated aragonite and water at low temperatures. Geochimica et Cosmochimica Acta 67, 387-399. 


\section{Figures}

Figure 1 Location of Eski Acıgöl and other major sites discussed in the text. Inset shows Eski Acıgöl basin morphology. Contours are m above sea level.

Figure $2 \delta^{18} \mathrm{O}$ curve from Eski Acıgöl (cores ESK96A/B and ESK97A/B) showing the steady-state phases investigated in this paper (vertical bars) plotted against changes in stratigraphy, U-series ages and the type of calcium carbonate present in the core (see Roberts et al. (2001) for details).

Figure 3 Contemporary climate values for three meteorological stations in Cappadocia (Niğde, 1208 masl, 37 59’ N, 34 40’ E; Nevşehir, 1260 masl, 38 35’’N, 34 40’E; Derinkuyu 1300 masl, 38 23' N and 34 45' E) for 1988 and 1989 (data from State Meteorological Services).

Figure 4 a) Sensitivity of evaporation to changing wind speed at different temperatures. All other parameters remain constant. b) Sensitivity of $\delta_{\mathrm{E}}$ to changing RH at different values of $\delta_{1}$. All other parameters remain constant.

Figure 5 Comparison between the precipitation records from Eski Acıgöl (black) and Soreq cave (grey) (based on Bar-Matthews et al., 1997; see text for details). Boxes show calculated precipitation ranges for different time periods within the two records. Lines between boxes are indicative only, and are not based on analytical measurements. The dashed line for Eski Acıgöl before c. 23,000 years is based on information from the Konya basin lake level record (see discussion in text). 
Table 1 Time periods used for modeling calculations, with palaeotemperature data (SSTs after Emeis et al., 2000) relative to present day.

\begin{tabular}{lcccc}
\hline $\begin{array}{l}\text { Time periods used in } \\
\text { this study }\end{array}$ & Age (ka) & \multicolumn{2}{c}{ Temperatures ( ${ }^{\circ}$ C relative to present) } \\
& & Ionian Sea SST & Levantine & Values used \\
& & & basin SST & here \\
\hline Late Holocene & $1.5 \pm 1.0$ & 0 & 0 & 0 \\
Early Holocene & $11.0 \pm 0.5$ & -4 & -1 & -1 \\
Late Glacial Stade & $12.5 \pm 0.5$ & -8 & & -5 \\
Late Glacial Interstade & $14.5 \pm 1$ & -1 & & -1 \\
Glacial & $19.0 \pm 3.0$ & -9 & -6 & -6 \\
\hline
\end{tabular}


Table 2 Ranges of possible lake depths and lake areas for the time periods under investigation in this paper.

\begin{tabular}{lccc}
\hline & $\begin{array}{r}\text { Lake Bottom } \\
\text { masl }\end{array}$ & Lake Depth & Lake Area \\
& 1,267 & $0-5$ & $\mathbf{m}^{\mathbf{2}}$ \\
\hline Late Holocene & 1,260 & $15-25$ & $393,425-550,795$ \\
Early Holocene & 1,259 & $10-20$ & $299,003-456,373$ \\
Late Glacial Stade & 1,258 & $15-25$ & $361,951-519,321$ \\
Late Glacial Interstade & 1,255 & $10-20$ & $236,055-393,425$ \\
Glacial & & & \\
\hline
\end{tabular}


Table 3 Lake water isotope values for the model time periods calculated from summer lake water temperatures.

\begin{tabular}{lcccc}
\hline & $\begin{array}{c}\boldsymbol{\delta}_{\text {carbonate }} \\
(\mathbf{\% o})\end{array}$ & $\begin{array}{c}\boldsymbol{\delta}_{\text {calcite }} \\
\mathbf{( \% o )}\end{array}$ & $\begin{array}{c}\mathbf{T}_{\text {lake }} \\
\left({ }^{\circ} \mathbf{C}\right)\end{array}$ & $\begin{array}{c}\boldsymbol{\delta}_{\mathbf{l}} \\
\mathbf{( \% o})\end{array}$ \\
\hline Late Holocene & 2.0 & 1.4 & 20.7 & 2.9 \\
Early Holocene & -3.0 & -3.0 & 19.7 & -1.7 \\
Late Glacial Stade & -0.5 & -1.1 & 14.7 & -0.7 \\
Late Glacial Interstade & -3.0 & -3.0 & 19.7 & -1.7 \\
Glacial & -0.5 & -1.1 & 13.7 & -0.9 \\
\hline
\end{tabular}


Table 4 Values for the calculations for each of the time periods (max and min in each case). Bold values are those calculated from the model;

shaded values are unknown; all other values are prescribed to the models as described in the text.

\begin{tabular}{|c|c|c|c|c|c|c|c|c|c|c|c|c|c|}
\hline Time period & $\begin{array}{l}\mathbf{T}_{\mathrm{av}} \\
{ }^{\circ} \mathrm{C}\end{array}$ & $\begin{array}{c}\mathbf{A} \\
\mathrm{m}^{2}\end{array}$ & $\begin{array}{c}\mathbf{p} \\
\mathrm{m} \mathrm{yr}^{-1}\end{array}$ & $\begin{array}{c}\mathbf{P} \\
\mathrm{m}^{3}\end{array}$ & $\begin{array}{l}\delta \mathbf{p} \\
\% \text { o }\end{array}$ & $\begin{array}{r}\mathbf{G}_{\mathbf{i}} \\
\mathrm{m}^{3}\end{array}$ & $\begin{array}{c}\delta_{\mathrm{Gi}} \\
\% \mathrm{o}\end{array}$ & $\begin{array}{c}\mathbf{P}+\mathbf{G i} \\
\mathrm{m}^{3}\end{array}$ & $\begin{array}{c}\mathbf{e} \\
\mathrm{m} \mathrm{yr}^{-1}\end{array}$ & $\begin{array}{c}\mathbf{E} \\
\mathrm{m}^{3}\end{array}$ & $\begin{array}{l}\delta_{\mathrm{E}} \\
\% \text { \% }\end{array}$ & $\begin{array}{l}\text { Go } \\
\mathrm{m}^{3}\end{array}$ & $\begin{array}{c}\delta_{\mathrm{Go}} \\
\% \text { o }\end{array}$ \\
\hline \multirow[t]{2}{*}{ Late Holocene } & 10 & 267,529 & 0.36 & 96310 & -10.2 & 192,621 & -10.2 & 288,931 & 1.08 & 288,931 & -9.3 & $\mathbf{0}$ & 2.9 \\
\hline & 10 & 346,214 & 0.36 & 124637 & -10.2 & 249,274 & -10.2 & 373,911 & 1.08 & 373,911 & -9.3 & $\mathbf{0}$ & 2.9 \\
\hline \multirow[t]{2}{*}{ Early Holocene } & 9 & 393,425 & & & -10.5 & & -10.5 & 516,907 & 0.94 & 369,820 & -14.0 & 147,087 & -1.7 \\
\hline & 9 & 550,795 & & & -10.5 & & -10.5 & 723,670 & 0.94 & 517,747 & -14.0 & 205,922 & -1.7 \\
\hline \multirow[t]{2}{*}{ Late Glacial Stade } & 5 & 299,003 & & & -10.9 & & -10.9 & 219,503 & 0.52 & 155,482 & -15.1 & 64,022 & -0.7 \\
\hline & 5 & 456,373 & & & -9.9 & & -9.9 & 371,448 & 0.52 & 237,314 & -15.1 & 134,134 & -0.7 \\
\hline \multirow[t]{2}{*}{ Late Glacial Interstade } & 8 & 361,951 & & & -10.4 & & -10.4 & 422,418 & 0.8 & 289,561 & -14.3 & 132,857 & -1.9 \\
\hline & 8 & 519,321 & & & -9.9 & & -9.9 & 643,958 & 0.8 & 415,457 & -14.3 & 228,501 & -1.9 \\
\hline \multirow[t]{2}{*}{ Glacial } & 4 & 236,055 & & & -10.8 & & -10.8 & 138,295 & 0.4 & 944,22 & -15.4 & 43,873 & -0.9 \\
\hline & 4 & 393,425 & & & -9.3 & & -9.3 & 271,651 & 0.4 & 157,370 & -15.4 & 114,281 & -0.9 \\
\hline
\end{tabular}


Table 5 Values to investigate the controls on $\delta_{\text {calcite }}$ in the Eski Acıgöl system. $\mathrm{r}^{2}$ values show the strength of the relationship with $\delta_{\text {calcite. }}$ LH $=$ Late Holocene, EH = Early Holocene, LGS = Late Glacial Stade, LGIS = Late Glacial Interstade, G = Glacial.

\begin{tabular}{|c|c|c|c|c|c|c|c|c|c|c|c|c|c|c|}
\hline & $\begin{array}{c}\delta^{18} \mathbf{O}_{\text {calcite }} \\
\% \\
\% \\
\end{array}$ & $\begin{array}{c}\mathrm{p} \\
\mathrm{m} \mathrm{yr}^{-1} \\
\end{array}$ & $\begin{array}{c}\mathrm{e} \\
\mathrm{m} \mathrm{yr}^{-1} \\
\end{array}$ & p:e & $\begin{array}{c}\mathbf{A} \\
\mathbf{m}^{2} \\
\end{array}$ & $\begin{array}{c}\mathbf{P} \\
\mathbf{m}^{3} \\
\end{array}$ & $\begin{array}{c}\mathbf{E} \\
\mathbf{m}^{3} \\
\end{array}$ & $\begin{array}{l}\mathbf{Q i} \\
\mathbf{m}^{3} \\
\end{array}$ & Qi:E & $\begin{array}{c}\text { Volume } \\
\mathbf{m}^{3} \\
\end{array}$ & $\begin{array}{c}\text { Residence } \\
\text { Time } \\
\text { years } \\
\end{array}$ & $\begin{array}{r}\mathbf{G i} \\
\mathbf{m}^{3} \\
\end{array}$ & $\begin{array}{l}\text { Go } \\
\text { m }^{3} \\
\end{array}$ & $\begin{array}{c}\text { Depth } \\
\text { m } \\
\end{array}$ \\
\hline \multirow[t]{2}{*}{ LH } & 1.4 & 0.28 & 0.94 & 0.30 & 267,529 & 74,908 & 251,477 & 288,931 & 1.15 & 0 & 0.00 & 214,023 & 0 & 0 \\
\hline & 1.4 & 0.36 & 1.23 & 0.29 & 346,214 & 124,637 & 425,843 & 373,911 & 0.88 & $1,517,635$ & 4.06 & 249,274 & 0 & 5 \\
\hline \multirow[t]{2}{*}{ EH } & -3.0 & 0.33 & 0.80 & 0.41 & 393,425 & 129,830 & 314,740 & 433,642 & 1.38 & 4,552,905 & 10.50 & 303,812 & 118,902 & 15 \\
\hline & -3.0 & 0.45 & 1.08 & 0.42 & 550,795 & 247,858 & 594,859 & 834,170 & 1.40 & $7,588,175$ & 9.10 & 586,312 & 239,311 & 25 \\
\hline \multirow[t]{2}{*}{ LGS } & -1.1 & 0.18 & 0.40 & 0.45 & 299,003 & 53,821 & 119,601 & 168,371 & 1.41 & $3,035,270$ & 18.03 & 114,550 & 48,769 & 10 \\
\hline & -1.1 & 0.30 & 0.65 & 0.46 & 456,373 & 136,912 & 296,642 & 466,152 & 1.57 & $6,070,540$ & 13.02 & 329,240 & 169,510 & 20 \\
\hline \multirow[t]{2}{*}{ LGIS } & -3.0 & 0.40 & 0.80 & 0.50 & 361,951 & 144,780 & 289,561 & 422,418 & 1.46 & $4,552,905$ & 10.78 & 277,638 & 132,857 & 15 \\
\hline & -3.0 & 0.50 & 1.08 & 0.46 & 519,321 & 259,661 & 560,867 & 888,646 & 1.58 & $7,588,175$ & 8.54 & 628,986 & 327,779 & 25 \\
\hline \multirow[t]{2}{*}{ G } & -1.1 & 0.13 & 0.29 & 0.45 & 236,055 & 30,687 & 6,456 & 61,421 & 0.90 & 2,361,655 & 38.45 & 30,734 & 31,490 & 10 \\
\hline & -1.1 & 0.27 & 0.52 & 0.52 & 393,425 & 106,225 & 204,581 & 354,936 & 1.73 & 5,396,925 & 15.21 & 248,711 & 150,355 & 20 \\
\hline $\mathbf{r}^{2}$ & & 0.187 & 0.004 & 0.486 & 0.350 & 0.317 & 0.100 & 0.283 & 0.323 & 0.645 & 0.037 & 0.268 & 0.569 & 0.634 \\
\hline p & & 0.212 & 0.861 & 0.025 & 0.072 & 0.090 & 0.373 & 0.113 & 0.087 & 0.005 & 0.596 & 0.125 & 0.012 & 0.006 \\
\hline
\end{tabular}





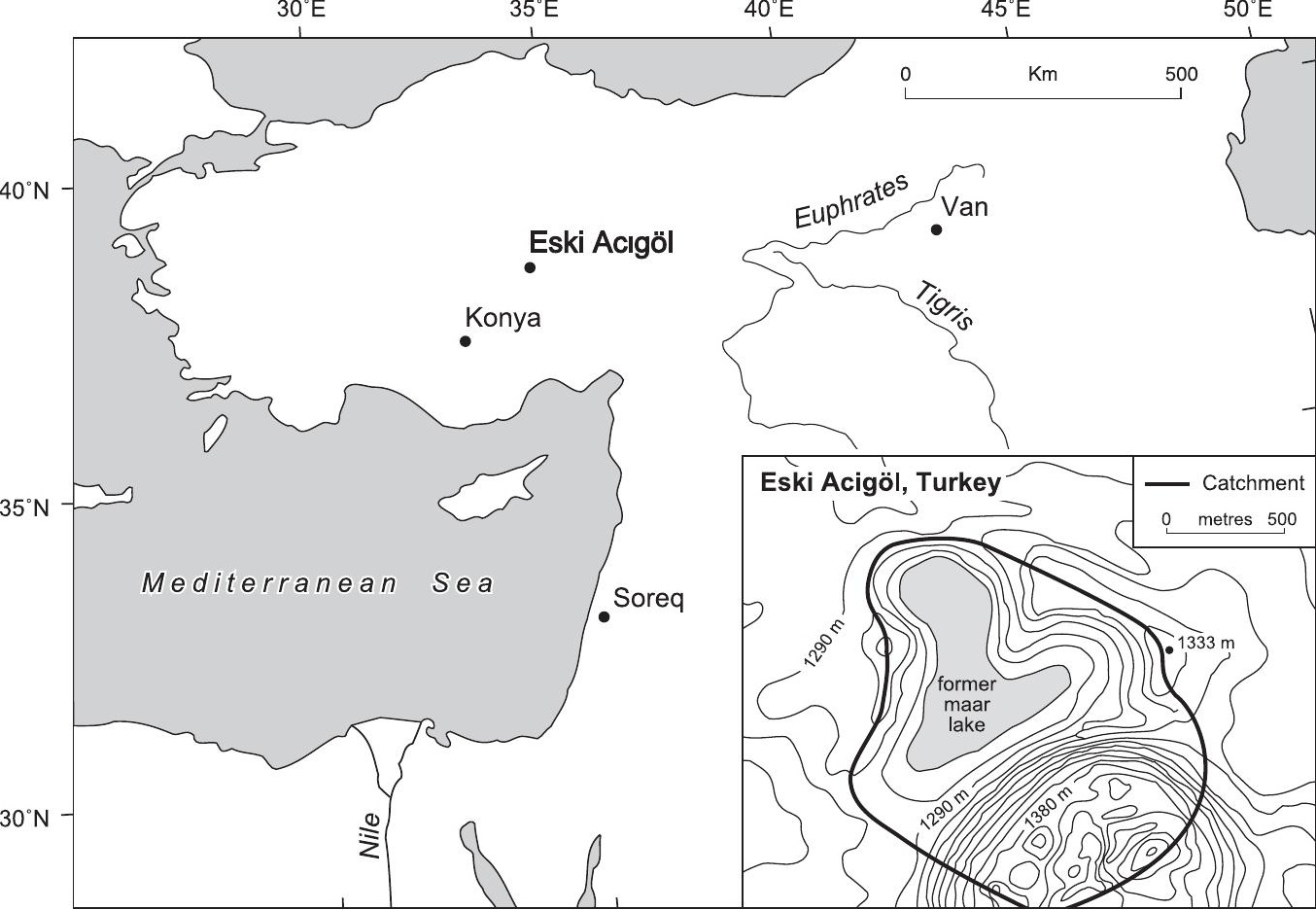


